\title{
Literary Translingualism: What and Why?
}

\author{
Steven G. Kellman \\ University of Texas at San Antonio \\ 1 UTSA Circle, San Antonio, TX 78249
}

The article is devoted to a comprehensive understanding of the theory of translingualism. Its author, Professor Steven Kellman, discusses the essence of the term he proposed in the context of world literature, citing numerous examples of translingual imagination. Based on the work of writers such as Joseph Conrad, Vladimir Nabokov and others, Professor Kellman demonstrates how the mechanism of intercultural and translational interaction of linguistic and extralinguistic elements works in each individual case. The theory of translingualism enriched the cycle of the humanities (from linguistics to cultural studies, from literary criticism to philosophy) with a new popular episteme, which the editorial board gladly shares with our readers.

Key words: translingualism, translingual imagination, transculturation, intercultural communication, literary text

\section{Introduction}

I define literary translingualism as the phenomenon of writers who create texts in more than one language or in a language other than their primary one. The multinational, multicultural, multilingual Russian Federation, in which Chingiz Aitmatov and Gennadii Aigi wrote in their native Kyrgyz and Chuvash, respectively, as well as Russian, is a natural incubator for translingual literature. And RUDN, whose students hail from 156 countries, is an appropriate venue for its study. Many other countries, including Canada, France, India, Israel, Nigeria, South Africa, the United Kingdom, and the United States, have produced important translingual texts. Germany even established an annual award named the Adelbert von Chamisso Prize, after a nineteenth-century poet who wrote in German, not his native French - to honor writers who write in German as an adopted language. During the past two decades, the study of translingualism has burgeoned through university seminars, dissertations, conferences, journal articles, and monographs.

Writing well demands painful sacrifice. "It is only when you open your veins and bleed onto the page a little" wrote Paul Gallico, "that you establish contact with your reader" [1. P. 576]. Anyone who has ever tried to write a book might agree with George Orwell's assessment that it is "a horrible, exhausting struggle, like a long bout of some painful illness" [2. P. 395]. So why would any sane person exacerbate the horror by contending

(C) Kellman S.G., 2019

This work is licensed under a Creative Commons Attribution 4.0 International License 
with the additional burden of a foreign language's unfamiliar vocabulary and grammar? Writing in L2 means accepting an additional handicap, like the 30 pounds of firefighting gear that, in order to honor the memory of a fellow firefighter, James Gefke carried while finishing the 2011 Boston Marathon in four hours, 18 minutes, and 29 seconds. Joseph Conrad described the ordeal of writing in English rather than his native Polish as akin to arduous physical labor: "I had to work like a coal-miner in his pit quarrying all my English sentences out of a black night" [3. P. 82-83].

Furthermore, some notable authorities have insisted that no one can write anything of value except in L1. German Romanticism posited that for each nation and each individual there is only one language capable of expressing the authentic spirit. During the course of articulating a theory of translation in his 1813 essay "Über die verschiedenen Methoen des Übersezens" ("On the Different Methods of Translating"), Friedrich Schleiermacher casually denies the possibility of translingual literature, declaring that it is not possible to write something of artistic merit in a foreign language: "es nicht möglichistet was der Uebersetzung, sofernsie Kunst ist, würdiges und zugleich bedürftigesurspränglich in einerfremden Sprachezuschreiben [4. P. 77]. Thomas Jefferson, who spoke French fluently and studied Greek and Latin, proclaimed that: "No instance exists of a person's writing two languages perfectly" [5. P. 249]. Though no person ever writes perfectly in even one language, Petrarch's poems in Italian and Latin, Rainer Maria Rilke's in French and German, and Fernando Pessoa's in Portuguese and English refute Jefferson. A long roster of other translinguals, from Walter Abish and Chinua Achebe to Feridun Zaimoğlu and Louis Zukofsky, testifies to the fact that cultural production in an adopted language is quite possible after all.

\section{Discussion}

Most people in the world are multilingual, though most people are not writers. All of us negotiate multiple registers even within a single language. However, an isolingual writer writes only in L1. Though he could read half a dozen languages, Johann Wolfgang von Goethe wrote only in German and was thus, like Virgil, William Shakespeare, and William Faulkner, an isolingual author. By contrast, it might be useful to distinguish between two categories of translingual writer. An isolingual translingual (if that is not a contradiction in terms) switches languages and writes exclusively in the adopted language, whereas an ambilingual translingual writes in more than one language. Because he did all of his writing in French rather than his native Serer, Léopold Sédar Senghor would be classified as an isolingual translingual. So is Elias Canetti, who wrote in German and not Ladino, his L1. However, because he wrote his books sometimes in Afrikaans and sometimes in English, André Brink is an ambilingual translingual. So, too is Prem Chand, a major figure in both Urdu and Hindi.

The most prominent translingual authors of the twentieth century are Joseph Conrad, Samuel Beckett, and Vladimir Nabokov. Each represents a unique example of translingualism. Born Josef Józef Teodor Konrad Korzeniowski in what is now Ukraine, Conradgrew up speaking Polish. As sixteen, taking advantage of his knowledge of French, he shipped out of Marseille as a sailor on French merchant vessels. When poor health at 
age thirty-six forced him to retire from the sea, he settled in England. His command of English was rudimentary, and his wife recalled that to his dying day he spoke the language with such a thick Polish accent that she often could not understand what he was saying. Nevertheless, as the author of Heart of Darkness, Nostromo, The Secret Agent, and Under Western Eyes, he managed to make himself into one of the canonical modern English novelists. Since all of his fiction was written in English, not Polish or French, Conrad was an isolingual translingual.

Born in Ireland, Beckett grew up speaking English, and wrote his first books of poetry, fiction, and nonfiction in English. However, after settling in Paris, he fulfilled his ambition of becoming a French writer, with notable works such as Molloy, Malone meurt, L'Innommable, En attendant Godot, and Fin de partie. An ambilingual translingual, Beckett also translated many of his French writings into English.

Vladimir Nabokov grew up in St. Petersburg amid wealth and privilege. From an early age, his command of Russian was complemented by private tutoring in French and English, so that he was effectively trilingual. In 1917, the family fled the Revolution, settling in Berlin, where Nabokov began a career writing poetry, drama, and fiction in Russian; since his work was banned in the Soviet Union, he was writing for the small community of Russian émigrés. When the Nazis came to power, he and his Jewish wife left Berlin for Paris, where he began writing in French. But when the German armies invaded France, Nabokov began his career all over again, on the other side of the Atlantic, writing in English. Works such as Lolita, Pnin, and Pale Fire established him as a major figure in Anglophone literature. However, if he had died in 1938, before ever moving to America, works such as Защита Лужина, Отчаяние, and Дар would have still earned him a prominent place in modern Russian literature. Had he been able to remain in France, he might well have become a formidable force in French literature. Nabokov clearly qualifies as a preeminent ambilingual translingual.

The many, many other translingual writers - both isolingual and ambilingual - of recent times include S.Y. Agnon, Edwidge Danticat, Assia Djebar, Aleksandar Hemon, Fazil Iskander, Milan Kundera, Ngũgĩ wa Thiong'o, Yoko Tawada - in fact, most of the most prominent writers from Africa and Asia, who adopted the language of a European colonial power for their literary expression. But translingualism also has an ancient pedigree. Much of classical Latin literature was created by outlanders such as Apuleius, Ausonius, Lucan, Martial, Quintillian, Seneca, and Terence - provincials who adopted the language of imperial Rome as their literary medium. Even earlier, it is quite possible that Anatolians, Carthaginians, Etruscans, and other peoples of the Mediterranean basin and Asia Minor appropriated the newly devised alphabet introduced to them by the seafaring Phoenicians not only by adapting it to their own unlettered tongues but also by writing in Phoenician. Even earlier than that, as far back as the $23^{\text {rd }}$ century B.C.E., when the first poet history knows by name, Enheduanna, the only daughter of the powerful Akkadian king Sargon, wrote in Sumerian, though her first language was probably Akkadian. Within the far-flung empires of antiquity, subjects wrote in the imperial language - Greek, Latin, Persian, Arabic, Chinese, Sanskrit - regardless of what they spoke at home. Indeed, Yasemin Yildiz [6. P. 2] argues persuasively that what she calls "the monolingual paradigm" is an historical aberration that first emerged in late- 
eighteenth-century Europe. Throughout the rest of history, multilingualism has otherwise been the norm, and writers have not felt constrained to stick with L1. Long before James Joyce made of Finnegans Wake a potpourri of multilingual puns and Leo Tolstoy alternated his Russian narration with aristocrats' dialogue in French, the medieval Goliardic poets employed code-switching in their macaronic verse.

Like Tolstoy's unhappy families, all translinguals are translingual in their own way. Yet they do share a certain set of motivations for taking on the daunting challenge of writing in an adopted language. One common and obvious impetus is migration. It is natural for newcomers to try to assimilate to a new home, often chiefly by learning its language. Milan Kundera had already established himself as a leading Czech novelist when, in his forties, he resettled in France and began writing in French. After moving to the United States, Ha Jin has written all of his fiction in English, not his native Chinese. Many immigrant memoirs - by Ariel Dorfman, Eva Hoffman, Luc Sante, IlanStavans, and others-are also what Alice Kaplan has dubbed "language memoirs", accounts of how the author fashioned a new self in a new land in a new language. Mary Antin's classic 1912 autobiography, The Promised Land, celebrates how, moving from Polotsk (then part of the Russian Empire, now in Belarus) to Boston, she becomes American by learning to "think in English without an accent" [7. P. 282]. Antin's book, so proudly American and Anglophone that she even omits any mention of the language she left behind, Yiddish, is proof of her linguistic triumph.

However, in contrast to writers who switch languages because they switch countries are those who stubbornly cling to their native tongues far from the environs where they are usually spoken. Though he spent almost twenty years in the United States, Aleksandr Solzhenitsyn never made much effort to learn English, instead focusing on fulfilling his mission of writing, in Russian, the searing documents of oppression that had made him persona non grata in the country of his birth. Julio Cortázar lived in France for the last three decades of his life, but he continued to write in Spanish, not the ambient language, French. And, though Isaac Bashevis Singer, who was born in Poland, spent most of his life in the United States, and though he learned to speak fluent English, he insisted on composing all of his fiction in Yiddish, a language whose readership he realized had turned into ghosts.

Imperialism - military, political, cultural, or commercial - accounts for another large share of translinguals. The hegemony of a conquering culture accounts for many of the texts composed in Arabic, Chinese, Latin, Persian, and Sanskrit by non-native speakers. In modern times, control of Africa and Asia by colonial European powers ensured that indigenous writers chose English, French, or Portuguese as their literary medium, rather than Bengali, Vietnamese, Fulani, Malayalam, or Zulu. The question of what is the appropriate language for an African writer has been the subject of fierce debate among African writers themselves. Ngũgĩ waThiong’o, who began his career publishing novels in English and under the name James Ngugi, eventually decided that he was betraying his people by not writing in their indigenous language. He vowed to write all of his subsequent books in his native Gikuyu, though he also later translates them into English. Since Gikuyu is only one of many languages spoken in Ngũgĩ's Kenya, it is ironic that his most of his compatriots cannot read him in the authentic African language 
he has chosen. Chinua Achebe, by contrast, wrote exclusively in English, not his native Igbo, which, however, had not yet developed a written form when he published Things Fall Apart in 1958. Achebe has argued that he and other colonial subjects have appropriated and transformed the European language and made it their own, an African English. As Salman Rushdie, who claims Urdu as his first language but writes in English, put it, "the Empire writes back with a vengeance" [8]. In Shakespeare's The Tempest, Caliban employs the words of the colonizer to express a subaltern's resentment when he tells Prospero: "You taught me language, and my profit on 't/ Is, I know how to curse" (Act 1 Scene 2, 11. 437-8).

In the modern global economy, commercial pressures can be as persuasive as military and political ones in inducing writers to switch languages. Certain world languages Arabic, Chinese, English, French, Spanish - promise access to a much more extensive readership than, say, Finnish, Khmer, or Tajik. A native speaker of one of the latter who wants to write a bestseller, or merely earn a living, might consider it prudent to adopt a language with a wider currency.

Perhaps the most interesting class of translinguals are those who switch languages not because they were pressured to for one reason or another but, rather, out of a conscious exercise of free will. The artificial language Esperanto, concocted in 1887 by Ludwik Zamenhof, has virtually no native speakers. Esperantists are idealists who learn and use it as an auxiliary tongue that they believe can overcome nationalistic barriers and promote understanding and peace. The corpus of fiction, nonfiction, poetry, and drama that has been created in Esperanto represents translingual choice.

So, too, does modern Hebrew literature, which began to be created at the end of the nineteenth century, almost two thousand years after Hebrew had ceased to be a living language. It remained as the language of liturgy and scholarship, but Jewish nationalists aimed to revive it as a vibrant primary tongue that would solidify the bonds among a scattered people. They succeeded in an extraordinary feat of linguistic resuscitation, to the extent that Hebrew is now the first language of more than five million people. But the first two or three generations of modern Hebrewwriters, figures including S.Y. Agnon, Aharon Appelfeld, Chaim Nachman Bialik, and Shaul Tschernikhovsky, were translingual; they chose to write in Hebrew, though it was their second, third, or even fourth language, after Arabic, German, Polish, Russian, or Yiddish.The attempt to revive the Irish language has not been quite as successful, but modern Irish literature, created by writers such as Brendan Behan and Brian O'Nolan whose L1 has usually been English, is translingual.

Switching languages is a way of inventing a new self, sometimes signaled by a change in name. Thus, Karen Blixen signed her works Isak Dinesen when she wrote in English rather than her native Danish. Shmuel Yosef Halevi Czaczkes changed his name to S.Y. Agnon when he began to write in Hebrew rather than his native Yiddish. Jin Xuefei adopted the identity of Ha Jin when he adopted English, not Chinese, as his literary language. And Brian O'Nolan became Flann O'Brien when he wrote in English but Myles nagCopaleen when he wrote in Irish.Born in Vilna, Roman Kacew became a successful author through the novels he wrote in French under the byline Romain Gary, though he also on occasion used the pseudonyms Émile Ajar, Fosco Sinibaldi, and Shatan Bogat. Of course not every writer wishes to undergo the perilous process of altering identity. 
Though he lived in California for almost forty years, Czesław Miłosz continued writing in his first language, Polish. He explained that: "In my rejection of imposing a profound change on myself by going over to writing in a different language, I perceive a fear of losing my identity, because it is certain that when we switch languages we become someone else" [9. P. 220].

The vertigo of loss of self is sometimes, for translinguals, also accompanied by guilt over betrayal. Many languages use a maternal metaphor to refer to L1. In English, it is the mother tongue. In others, it is maternamlocutionem, Muttersprache, langue maternelle, madrelingua, idiomamaterno, 語, modersmål, anyanyelvük, פאה תפש. Языкматери, ושאָל

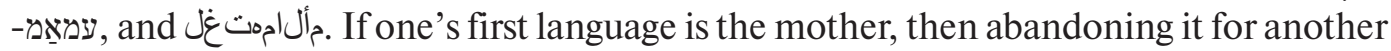
becomes a kind of psychic matricide.

In sharp contrast to Miłosz's refusal to forsake his mother tongue is the case of Jhumpa Lahiri, a particularly dramatic instance of self-transformation through willful translingualism. Though she grew up in Massachusetts in a Bengali-speaking family, Lahiri spoke English from an early age and grew up to achieve considerable critical and commercial success with two novels - The Namesake and The Lowland - and two collections of short stories - Interpreter of Maladies and Unaccustomed Earth - in the dominant language of the United States. However, during a visit to Italy, Lahiri fell in love with its language and, despite lacking any familial connection to Italy, determined to learn Italian well enough to write solely in that language. In 2015, she published In Altre Parole, a language memoir - in Italian - that is a record of her love affair with Italian and her aversion to English, the language she used to secure her position as a leading contemporary American writer. Lahiri's translingual embrace of Italian is willful and risky.

Like the trilingual options available to Nabokov, raised in a wealthy Russian family that provided him with private tutors in French and English, the ability to choose among languages is a product of privilege. Unlike the medieval aristocrats who created kanshi, poetry composed in Chinese by Japanese writers, most of the sixty million refugees in the world today must accommodate themselves to the languages of the countries they find themselves in. However, the notorious Oscar Wilde chose to make a point by writing his scandalous play Salomé in French rather than his native English.He was thumbing his nose at the English, the historical oppressors of his Irish people, and, eroticizing a hallowed Biblical story, he was deliberately using a language that the prim Victorians of England associated with libertine transgressions across the Channel.

Because of their linguistic dexterity, translingual writers are uniquely equipped for autotranslation. Notable examples of writers who translated themselves include Beckett, Brink, Dinesen, Dorfman, and Nabokov. They are at legally free to take liberties with their own texts, even to reconceive them, that a hired professional translator would not dare. However, many translinguals find the task of self-translation an agony they would as soon forego. About the ordeal of refashioning his Russian novel «Отчаяние» into English as Despair, Nabokov complained it was "a terrible thing, translating oneself, sorting throughone's own innards, then trying them on for size like a pair of gloves" [10. P. 65]. Lahiri refused to translate her own Italian memoir In Altre Parole and was pleased to have the job consigned to the acclaimed professional translator Ann Goldstein, who rendered it as In Other Words. 
It is possible to identify and discover anecdotal information about thousands of translingual writers while still begging some urgent fundamental questions: What difference does translingualism make - for the writer and for the reader? Is it possible to perform a blind test on an unknown text and determine entirely from its style, structure, or themes whether it was written in an adopted language? Are certain genres more conducive than others to translingualism - Is it more difficult to write poetry or prose in L2?

For Rafael Sabatini, these questions were not important. Writing thirty-one novels, including popular successes such as Captain Blood, Scaramouche, and The Sea Hawk, in his sixth language, English, he did not fuss over language choice as long as he could attain a transparent style that does not call attention to itself but invites readers to lose themselves in the colorful adventures of his characters. The Indian novelist Raja Rao also dismissed the entire subject. "The important thing", he contended, in English, not his native Kannada, "is not what language one writes in, for language is really an accidental thing. What matters is the authenticity of experience, and this can generally be achieved in any language" [11. P. 147].

However, for Ludwig Wittgenstein, language is not merely incidental but, instead, determinative. We think, he thought, in language, and the particular language in which we think enables and constrains the thoughts we have: "Die Grenzenmeiner Sprachebedeuten die Grenzenmeiner Welt" [The limits of my language are the limits of my world] [12. P. 148-49]. Proponents of the controversial Sapir-Whorf Thesis of linguistic determinism maintain that each language embodies a unique Weltanschaaung. "We dissect nature along lines laid down by our native languages" [13. P. 213], contended Benjamin Lee Whorf. So it would follow that the decision Yoko Tawada makes with each book of whether to write in German or Japanese is not merely a matter of typography.

Different languages orient us differently toward space and time, and a language that lacks a past tense embodies a very different sense of history than one with a complicated preterite system of simple past, past perfect, past progressive, past perfect progressive, and habitual past. The English language has one all-purpose word, cousin, for numerous possible relationships - one's mother's brother's son, one's father's sister's daughter, father's brother's daughter, mother's sister's daughter, etc. It is arguable that a Russian speaker, with separate terms for each of those possibilities, is forced to think more clear about families. And perhaps it is appropriate that it was the great nineteenth-century Russians - Tolstoy, Dostoevsky, Turgenev - who wrote great novels of families, often beginning with family trees. Unlike Russian and English, Spanish has a complex system of subjunctives, ways of expressing and signaling something that is contrary to fact. Perhaps it is appropriate that the prototypical novel about a man obsessed by his fantasies, Don Quixote, was written, by Miguel de Cervantes, in Spanish.

So, whether they want to admit it or not, language choice certainly matters to writers. Since the Saami languages spoken above the Arctic Circle in Norway, Sweden, and Finland possess more than 180 snow- and ice-related terms, anyone attempting to write an epic about sleet could be more precise and nuanced in one of those languages rather than Fang, a language spoken in Equatorial Guinea [14]. Furthermore, many writers testify to the liberating effect of switching from L1. Anton Shammas, a Palestinian, explained to an interviewer - in English - why he chose to write his novel Arabesques in Hebrew 
rather than his native Arabic: "You cannot write about the people whom you love in a language that they understand. You cannot write freely. In order not to feel my heroes breathing down my neck all the time, I used Hebrew" [15. P. 48]. Hans Castorp in Thomas Mann's Der Zauberberg is also emancipated and emboldened by switching languages. Speaking French rather than his native German enables him to overcome his inhibitions about flirting with ClavdiaChauchat, a married Russian woman. As he tells her, enfrançais, using the intimate $t u$ though he would not have dared address her as $d u$ in German: "Moi, tu le remarques bien, je ne parleguère le français. Pourtant, avec toi je préfère cette langue à la mienne, car pour moi, parler français, c'est parler sans parler, en quelque manière, sans responsabilité, ou comme nour parlons en rêve" [16. P. 407] [As you'vesurelynoticed, I barelyspeak French. All the same, I would rather speak with you in it than in my own language, since for me speaking French is speaking without saying anything somehow with no responsibilities, the way we speak in a dream].

Writing in one's native tongue can seem natural, but the words can flow too profusely to qualify as craft. There is a virtue in slowing the flow, in being more deliberative. Working in a less familiar language, translingual writers are forced to weigh their words more carefully than they might in L1. For Puerto Rican novelist Rosario Ferré, writing in her second language, English, had the beneficial effect of enforcing caution, making her concentrate on verbal choices. "English makes me slow down", she explained. "I have to think over what I'm going to say twice, maybe three times - which is often healthy because I can't put my foot, or rather my pen, in my mouth so easily".

Language itself often becomes a theme in translingual writing, as for example when much of Nabokov's Pale Fire turns on a mistranslation from the fictional language Zemblan or when the narrators of Beckett's novelistic trilogy repeatedly express their contempt for words. Translingual writers tend to be more self-conscious about their choice of words, and, for readers of translingual literature, the verbal medium itself is foregrounded. For both writer and reader, language is defamiliarized, deautomatized, consistent with Viktor Shklovsky's theory of остранение. Language is made strange, because deployed in a strange tongue.

It might be supposed that, not confined to the prison-house of a single language, and thus a single Weltanschaaung, translingual writers exhibit a greater emotional resiliency and a wider imaginative range. Indeed, in her study of Russian writers, such as Mark Aldanov, Elsa Triolet, and Marina Tsvetaeva, who emigrated to France after the Revolution and wrote in French, Elizabeth Klosty Beaujour concludes that they share "cognitive flexibility", "tolerance for ambiguity", and "greater awareness of the relativity of things" [10]. Might this be what John Keats called "negative capability", a chameleon-like refusal of fixed identity that, in a December 21, 1817 letter to George and Tom Keats, he described as "when a man is capable of being in uncertainties, mysteries, doubts, without any irritable reaching after fact and reason" [17. P. 41]? However, as the paragon of negative capability, Keats offered the example of William Shakespeare, who wrote exclusively in English. Similarly is olingual, though he knew half a dozen languages, was Johann Wolfgang von Goethe. Since neither of those two literary masters lacked imaginative range, it might be necessary to remain, at least for the moment, in uncertainty, mystery, and doubt about whether there is anything unique to translingual writers. 


\section{Conclusions}

Solving such mysteries requires the talents and energies of generations of scholars literary specialists but also linguists, neurologists, biohistorians, and anthropologists. No one researcher possesses the linguistic equipment to take on the task alone. If there are approximately 5,000 languages in the world, the number of translingual possibilities would equal $5,000 \times 4,499 \div 2=12,497,500$. And that is only calculating the number of bilingual translingual possibilities; authors who, like Kamala Das, Vladimir Nabokov, and George Steiner, move among three or more languages add even more possibilities to the challenge of mapping out the universe of translingual literature. There remains much work for us all.

\section{References}

1. Gallico, P. 1946. Confessions of a Story Writer. New York: Knopf. Print.

2. Orwell, G. 1984. "Why I Write". The Orwell Reader: Fiction, Essays, and Reportage. San Diego: Harcourt. Print.

3. Conrad, J. 1927. Letter to Edward Garnett, August 28, 1908. In Joseph Conrad: Life and Letters, ed. C Jean Aubry. New York: Doubleday, Page. Print.

4. Schleiermacher, F. 2009. "Ueber die verschiedenen Methoden des Uebersezens". Dokumentezur Theorie der Übersetzungantiker Literatur in Deutschland seit 1800. Edited by Josefine Kitzbichler, Katja Lubitz, and Nina Mindt. Walter de Gruyter. pp. 59-82. Print.

5. Jefferson, T. 1999. Letter to John Banister Junior. October 15, 1785. Jefferson: Political Writings. Joyce Appleby and Terence Ball, eds. Cambridge, England: Cambridge University Press, 247-49. Print.

6. Yildiz, Y. 2012. Beyond the Mother Tongue: The Postmonolingual Condition. Fordham University Press. Print.

7. Antin, M. 1997. The Promised Land. Introduction and notes by Werner Sollors. Penguin. Print.

8. Rushdie, S. 1982. "Empire Writes Back With a Vengeance". Sunday Times, 2 July 1982: 8.4. Print.

9. Miłosz, C. 2001. Mitosz's ABC's. Trans. Madeline G. Levine. New York: Farrar, Straus and Giroux. Print.

10. Beaujour, E. 1989. Alien Tongues: Bilingual Russian Writers of the "First" Emigration. New York: Cornell University Press. Print.

11. Rao, R. 1992. "Raja Rao". In Interviews with Writers of the Post-Colonial World, ed. Feroza Jussawalla and Reed Way Dasenbrock, 140-55. Jackson: University Press of Mississippi. Print.

12. Wittgenstein, L. 1981. Tractatus Logico-Philosophicus. Ed. and trans. C.K. Ogden Boston: Routledge \& Kegan Paul. Print.

13. Whorf, B.L. 1956. Language, Thought, and Reality: Selected Writings. Ed. John B. Carroll. Cambridge, MA: MIT Press. Print.

14. Magga, O.H. 2006. "Diversity in Saami terminology for reindeer, snow, and ice". International Social Science Journal 58: 25-34. Print.

15. Shammas, A. 1988. "My Case Is Hopeless". Interview by Anne Zusy. New York Times Book Reivew, April 17, 1988, 48. Print.

16. Mann, T. 1974. Der Zauberberg. Berlin: S. Fischer. Print.

17. Keats, J. 2002. Selected Letters. Ed. Robert Gittings. New York: Oxford University Press. Print.

\section{Article history:}

Received: 07.06.2019

Accepted: 04.07.2019

Moderator: O.A. Valikova 


\title{
Conflict of interests: none
}

\section{For citation:}

Kellman, S.G. 2019. "Literary Translingualism: What and Why?". Polylinguality and Transcultural Practices, 16 (3), 337-346. DOI 10.22363/2618-897X-2019-16-3-337-346

\section{Bio Note:}

Kellman S.G. is a Professor at the Department of English, University of Texas at San Antonio. E-mail: steven.kellman@utsa.edu

\section{Литературный транслингвизм: что и почему?}

\author{
Келлман С.Г. \\ Техасский университет Сан-Антонио \\ 1 Университетский округ
}

Статья посвящена всестороннему осмыслению теории транслингвизма. Автор рассуждает о сущности предложенного им термина в контексте мировой литературы, приводя многочисленные примеры транслингвального воображаемого. На материале творчества таких писателей, как Джозеф Конрад, Владимир Набоков и другие, в статье показано, как срабатывает механизм интеркультурного и транслингвального взаимодействия языковых и внеязыковых элементов в каждом индивидуальном случае. Теория транслингвизма обогатила цикл гуманитарных наук (от лингвистики до культурологи, от литературоведения до философии) новой востребованной эпистемой, которой редколлегия с радостью делится с нашими читателями.

Ключевые слова: транслингвизм, транслингвальное воображение, транскультурация, межкультурная коммуникация, художественный текст

\section{История статьи:}

Дата поступления в редакцию: 07.06.2019

Дата принятия к печати: 04.07.2019

Модератор: О.А. Валикова

Конфликт интересов: отсутствует

\section{Для цитирования:}

Келлман С.Г. Литературный транслингвизм: что и почему? // Полилингвиальность и транскультурные практики. 2019. Т. 16. № 3. C. 337-346. DOI 10.22363/2618-897X-2019-16-3337-346

\section{Сведения об авторе:}

Стивен Келлман - профессор Департамента английского языка Техасского университета Сан-Антонио. E-mail: steven.kellman@utsa.edu 